\title{
核燃料サイクル開発機構において進められてきた再処理開発の成果と将来 ${ }^{\dagger}$
}

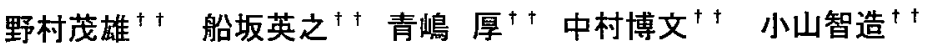

昭和 52 年 9 月（ホット試験の開始.なお, 本格操業は昭和 56 年 1 月.）に, 我が国初の再処理工場として核燃料サイ クル開発機構（当時の動力炉・核燃料開発事業団）の東海再処理工場がホット試験を開始して以来，約 20 年の歳月が経過 した．東海再処理工場における再処理方式は，海外で寒証済みの機械的前処理工程と溶媒抽出法（PUREX 法）を組み合わ せたものである.この間, 溶解槽の故障等幾多の経験を教訓としながら, 約 $936 t$ の軽水炉等の然料処理実績を挙げてきた.

一方，プルトニウムの有効利用に向けた高速増殖炉開発が行われる中で, 動燃において高速炉燃料の再処理技術の開発 に着手した．高速炬燃料は軽水炬燃料と比較して，ラッパ管等を有し，プルトニウム含有率が高く，高燃焼度化により核 分裂生成物含有量が多い等の特徵がある.このため, 高速炬燃料の再処理では, ラッパ管除去工程（解体工程）, 厳しい臨 界管理に耐える小型で処理能力の高い機器, 比放射能および不溶解残さの増加に対応した高性能機器が必要とされ, これ らの要求を満足する再処理機器を開発してきた. また, 近年では安全性・経済性の向上, 資源の有効利用, 環境負荷低減, 核不㧨散抵抗性の向上等, 社会の多様なニーズに対応するため,これまで赛績のある湿式 PUREX 法にとらわれない先進的 な技術の開発を進めている。

Keywords: 東海再処理工場, 軽水炉燃料再処理, 高速炉燃料再処理, 先進再処理

It has already passed 20 years since the Tokai reprocessing plant started its operation by Japan Nuclear Cycle Development Institute (JNC; former Power Reactor and Nuclear Fuel Development Corporation (PNC)) as the first reprocessing plant in Japan. The Tokai reprocessing plant has been operating with the mechanical head-end process and the solvent extraction (PUREX). While JNC had a lot of experiences such as the dissolver failure etc., the reprocessing amount achieved to 936 tons.

On the other hand, while the fast breeder reactor (FBR) development was carried out for realization of plutonium utilization, JNC started the development of the FBR fuel reprocessing technology. The FBR fuel reprocessing has different characteristics from LWR reprocessing as follows, wrapper tube, high plutonium content, high fission products content by high burn-up. Therefore, JNC has been developing the reprocessing equipment, which satisfied following requirements, wrapper tube removal process (dismantling process), high capacity and compact design at severe critical condition, corresponds to increase of the specific activity and insoluble sludge.

And also JNC has been started the advanced reprocessing technology with not only PUREX process but also advanced process, so as to meet various social needs, such as improvement of safety and economics, effective use of resource, decrease of environmental burden and improvement of non-proliferation.

Keywords: Tokai reprocessing plant, LBR fuel reprocessing, FBR fuel reprocessing, advanced reprocessing technology

\section{1 はじめに}

我が国では, 昭和 30 年代初頭, 原子力の平和利用のた めの研究開発が開始され，ウラン資源の有效利用の観点 から使用済み燃料を再処理し，ウランおよびプルトニウ ムをリサイクルする方針が打ち出された，その後，東海 再処理工場の建設計画が立案され，使用済み燃料に関す る再処理技術の開発がスタートした。

昭和 30 年代から 40 年代にかけて, 東海再処理工場の設 計・建設が進められ，昭和 52 年には，日本原子力研究所 (以下，原研と記す）の動力試験炉（JPDR）の使用済み燃 料を使つた国内初の再処理が開始された。また，昭和 55 年には原燃サービス株式会社 (日本原燃株式会社の前身)の 発足により，青森県六力所村における民間再処理工場の 建設が開始された. 現在, 平成 17 年の操業開始を目標に 工事が進められている。これらの施設における使用済み 燃料の再処理方法は, 機械的前処理工程と溶媒抽出法 (PUREX 法) を組み合わせたものであり，すでに海外で 実証されている方法である。

またフプトニウムの有効利用に向けた高速増殖炉の

$\dagger \quad$ Current Status and Future for Development of Reprocessing Technology in JNC, by Shigeo Nomura (nomura@tokai.jnc.go.jp), Hideyuki Funasaka, Atsushi Aoshima, Hirofumi Nakamura, Tomozo Koyama

$\dagger \dagger$ 核燃料サイクル開発機構環境保全・研究開発センター先進リサイク ル研究開発部 Waste Management and Fuel Cycle.Research Center, Advanced Fuel Recycle Technology Division, Japan Nuclear Cycle Development Institute $\bar{\top} 319-1194$ 茨城県那珅郡東海村村松 4 番地 33
開発が原研, 動力炉・核燃料開発事業団（核燃料サイクル 開発機構の前身．以下動然と記す）において行われる中で, 昭和 50 年以降, 高速炉燃料に関する再処理技術の開発が, 動燃を中心に進められ, 昭和 62 年には, リサイクル機器 試験施設（以下，RETF と記す.) の建設計画が立案され, 現在, 東海事業所において建設中である. また, 平成に 入ると, 新溶媒抽出剤等による先進再処理技術の開発も 開始されるようになった。

本報では，核燃料サイクル開発機構（以下，サイクル機 構と記す.）におけるこれまでの再処理技術の開発を中心 に, 再処理技術の現状と将来および先進再処理技術の開 発状沿について報告する。

\section{2 東海再処理工場の設計概要と運転成果}

\section{1 施設の目的=概要}

東海再処理工場は, 原子力発電による電力の安定供給 を確保するため, 国内再処理需要の一部を賄うとともに, 再処理技術の国内定着を図ることを目的とし, 昭和 52 年 以来約 20 年余りの運転実績を有している. 昭和 46 年 6 月に分離精製工場等の建設に着手し，通水作動試験およ び化学試験を経て, 昭和 50 年 9 月から昭和 52 年 3 月の 間に天然ウランを使用したウラン試験を行った. その後, 米国の核不拡散政策に関連した日米再処理交渉を経て昭 和 52 年 9 月よりホット試験を開始し, 昭和 55 年 4 月よ 
り使用前検査を受検, 昭和 55 年 12 月に合格証を受領し， 昭和 56 年 1 月から本格操業を開始した.

東海再処理施設の主要な建家は，分離精製工場，プル ト二ウム転換技術開発施設, 分析所, 廃棄物処理場, カ ラス固化技術開発施設，廃溶媒処理技術開発施設等であ る.

\section{2 工程の概要}

Fig.1 に再処理工程を示す．使用済み燃料の再処理は， 機械的前処理工程と湿式 PUREX 法を採用し，再処理能 力は 1 日当たり最大 $0.7 \mathrm{t}$ (金属ウラン換算) である.

\subsection{1 使用済み燃料の受入れおよび貯蔵工程}

再処理施設内に受け入れた使用済み燃料を，輸送キャ スクに収納したまま燃料取り出しプールに移動し，ここ で集合体を燃料バスケットに移し替えた後, 䝪蔵プール に貯蔵する。

\section{2 .2 機械処理工程}

貯蔵プールから, 燃料導入コンベアで然料を機械処理 セル内に搬入し，ガントリクレーン，燃料装荷台等でせ ん断機に送り込み, 集合体のまま長さ約 $3 \sim 4 \mathrm{~cm}$ の小片 にせん断する。 せん断燃料は, 分配器を経て溶解槽に供 給する。

\subsection{3 溶解-清澄工程}

溶解槽バレル内のバスケット内に装荷した燃料を，加 熱した硝酸により溶解する. 1 回当たりに溶解するウラ ン量は, BWR 型で 2 集合体約 $360 \mathrm{~kg}$, PWR 型で 1 集合 体約 $400 \mathrm{~kg}$ である. 冷却した溶解液は清澄工程に送り, パルスフィルタ（焼結金属製）で溶解液中の不溶解残さを 取り除き，抽出工程に供給する.

\subsection{4 分離工程}

ミキサセトラを用いた溶媒抽出法により，分離第 1 サ イクルで溶解液中のウランおよびプルトニウムと核分裂 生成物を分離し, 分離第 2 サイクルでウランとプルトニ ウムを分離する。

\subsection{5 精製工程}

分離工程と同様に，溶媒抽出法によりウランおよびプ ルトニウム溶液を，それぞれ精製する。精製された溶液 は蒸気により加熱され，蒸発・濃縮される。

\subsection{6 ウラン脱硝工程}

精製工程からの濃縮されたウラン溶液は，流動床型の ウラン脱硝塔において脱硝し，三酸化ウランとする．三 酸化ウラン粉末は，連続的に脱硝塔から抜き出し，専用 の容器に収納し、貯蔵する。

\subsection{7 酸および溶媒の回収工程}

分離第 2 サイクル，精製工程等から排出される中放射 性の液体廃棄物等を蒸気にて蒸発濃縮し, 発生する蒸気 を酸回収整流塔で精留して回収酸として回収する.また， 分離工程, 精製工程等で使用した有機溶媒を, 溶媒洗浄
器にて洗浄し, 分離工程, 精製工程等で再使用する.

\section{2 .8 放射性廃棄物の処理工程}

気体廃棄物は，槽類換気系とセル内換気系に区別し， 前者は洗浄塔，フィル夕等により，後者はフィルタによ り処理した後，主排気筒から放出する．液体廃棄物は， 高・中・低放射性に区別し，高放射性廃液は施設内貯蔵 またはガラス固化処理施設へ送り，ガラス固化体として 保管する，中放射性廃液は，酸回収工程で処理して低放 射性廃液とする。低放射性廃液は, 施設内貯蔵等を行う。

\section{2 .9 主要な試験施設}

マイクロ波加熱直接脱硝法によるウラン・プルトニウ ムの混合転換，リン酸による抽出分離法を用いた廃溶媒 処理, 高放射性廃液のガラス固化処理技術等の開発を行 っている.

\section{3 運転実績}

Fig. 2 に使用済み燃料の再処理実績を示す. 昭和 52 年 9 月に開始されたホット試験以降，平成 9 年 3 月までに処 理した使用済み燃料は合計約 $936 \mathrm{t}$ である。また，回收 プルトニウム量は約 $6 \mathrm{t}$ ，回収ウラン量は約 $888 \mathrm{t}$ であり， 回収プルトニウムは高速実験炉「常陽」, 新型転換炉「ふ げん」，高速増殖原型炉「もんじゅ」の燃料製造に用いら れ，回収ウランの一部は六フッ化ウランへの転換試験等 に利用されている。

昭和 56 年 1 月から本格的に操業運転を開始したが, 昭 和 57 年 4 月には溶解槽の故障, 昭和 58 年 2 月には 2 代 目酸回収蒸発午および 2 基目の溶解槽の故障により運転 が停止した. 昭和 60 年頃からは, 安定運転期に入ったが, 更なる稼働率の向上之運転日数の增加を目指し，施設の 計画停止による予防保全や再処理施設の定期検査方法の 改善による定期検査期閒の短縮を図り，年間 $90 \mathrm{t}$ 処理体 制が確立した. なお, 平成 8 年 3 月のアスファルト固化 処理施設の火災・爆発事故の影響により，平成 12 年 6 月 現在運転停止している.

\section{3. 高速炬燃料再処理技術開発の現状}

\section{1 前処理工程機器技術}

\subsection{1 解体工程機器}

高速炬燃料の特徵の 1 つして, 燃料ピンがラッパ管 と呼ばれる 6 角形のステンレス管の中に約められている ことから，再処理においては燃料集合体からラッパ管を 除去する解体工程が必要となる。

解体機の開発初期には，ラッパ管をメタルソーや砥石 で切断する装置を開発していたが，刃の摩耗が著しく頙 繁に交換が必要なことや燃料集合体の変形に追従させる 機棈が複雑になるなどの問題から，レーザビームによる 切断技術の適用を図ってきた. いくつかのレーザ解体試 


\section{夘プド回收技術開発}

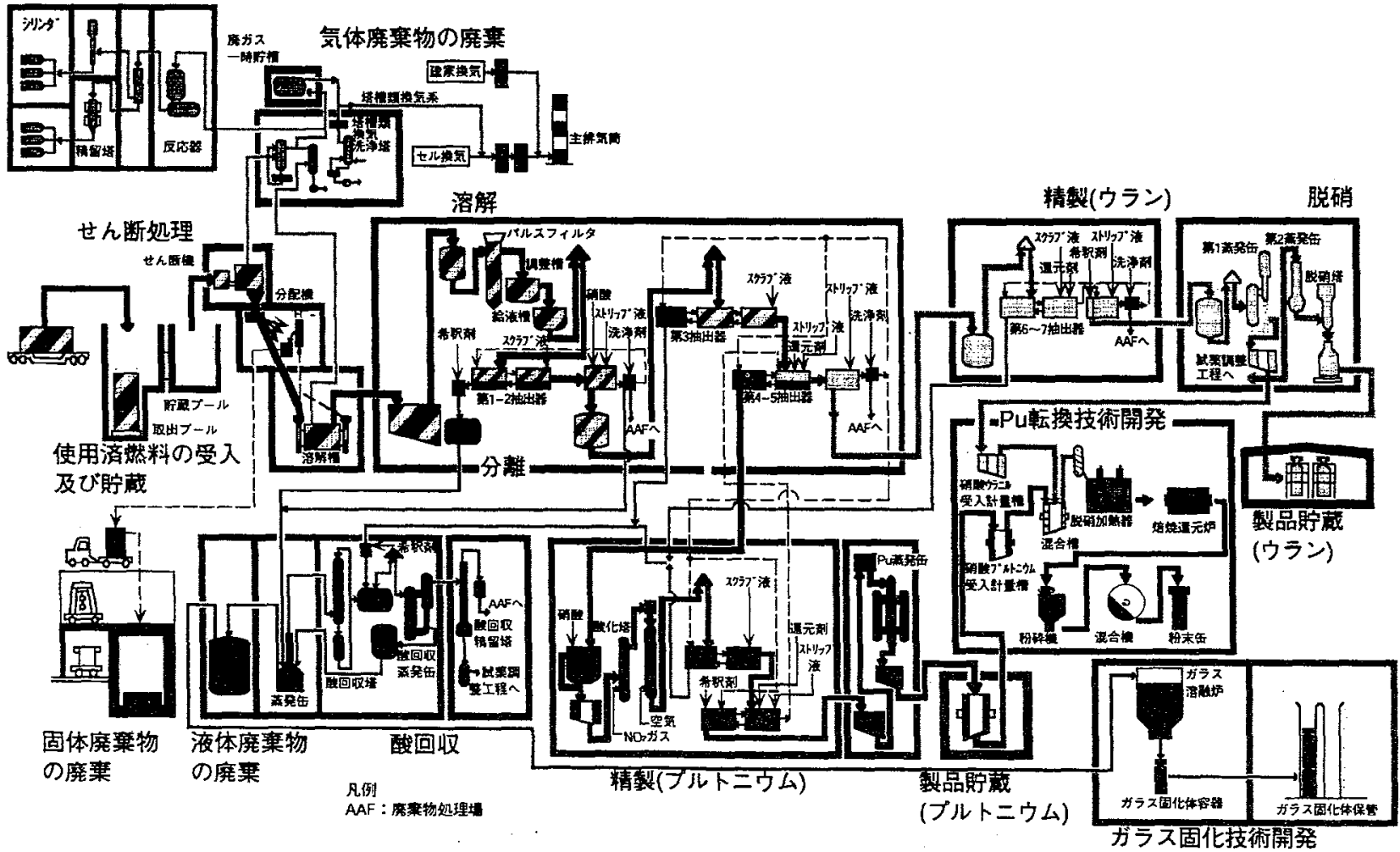

Fig.1 Process diagram for Tokai reprocessing plant

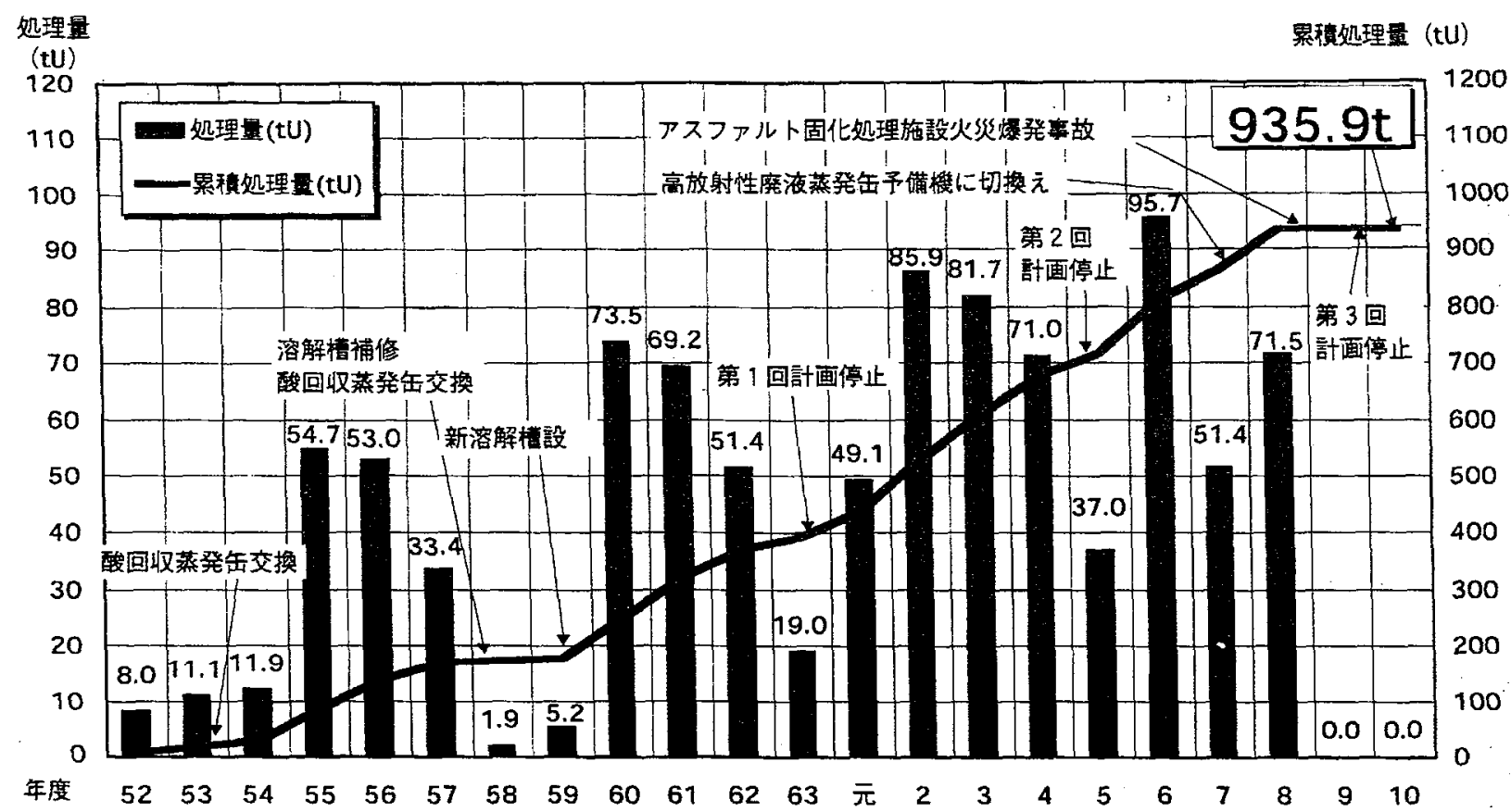

Fig.2 Throughput of spent fuel at Tokai reprocessing plant 


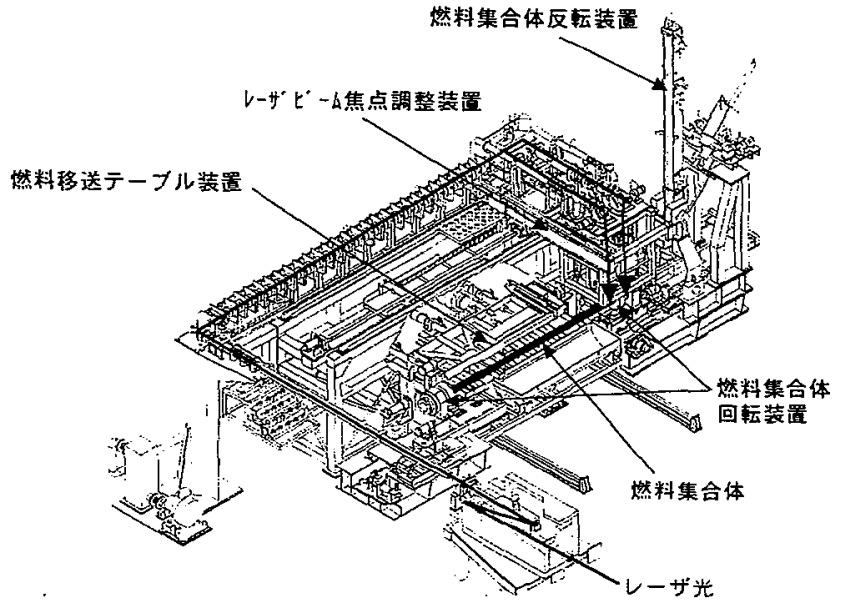

Fig.3 Fuel disassembly system

験機の試作を経て，現在は RETF 用のレーザ解体試験装 置のコールドモックアップを製作し，性能把握および RETF 設計への R\&D 結果のフィードバックを行ってきて いる.

本装置の概要を Fig.3に示す.使用しているレーザは炭 酸ガスレーザで, 最大出力 $10 \mathrm{~kW}$ のレーザ発振器（Fig.3 中では省略している）から出たレーザビームは 6 枚の反射 鏡で進路を曲げて最終的には発振器から最大で約 $26 \mathrm{~m}$ 離れた位置に焦点を結び，ここで切断を行う。燃料集合 体は両端を燃料回転装置でつかみ，撚料の中心を軸にし て回転することができる．ビームを集光するへッドは 2 種類あり，切断する対象物にあわせて切り替えて使える ようになっている.ビームの集光へッドは $\mathrm{X}, \mathrm{Y}, \mathrm{Z}$ の 3 方 向に移動することができるため，燃料の回転とラッパ管 切断用集光へッドの移動とを組み合わせることによって 小出力のレーザビームでラッパ管を切断していく.

その後，燃料切り落とし用の集光ヘッドを使い，むき 出しになった燃料ピン束の一端を高出カレーザで輪切り にし，解体機の横に設置しているせん断機のマガジンの 中に燃料ピン束を挿入する.

\subsection{2 せん断工程機器}

高速炬燃料は，軽水炬燃料に比べ燃料ピンの径が小さ く, スペーサの代わりに燃料ピンにワイヤが巻き付けら れていることが特徽である.このような燃料のせん断機 として，軽水炬再処理で実績のある水平せん断方式で開 発してきた.

従来から実績のあるせん断機では，せん断刃を駆動す るシリンダはセル壁を貫通する油圧シリンダであり，燃 料はマガジン端面から装荷されるが，RETF 用のせん断 試験装置は，セル内レイアウトの関係から装置全体をセ ル内に設置するため油を使わない水圧シリンダを採用し，

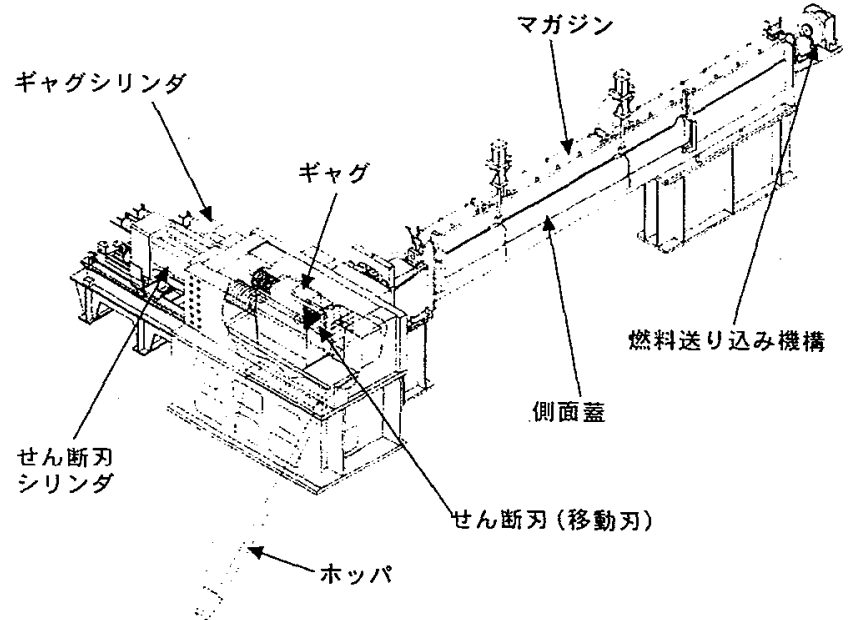

Fig.4 Shearing machine

またレーザ解体試験装置と並べて設置されるため燃料を マガジン側面から装荷する方式を採用している.

このせん断試験装置のコールドモックアップの概要を Fig.4 に示す. 解体機で解体された燃料ピン束は，側面蓋 を開けた状態でマガジン内に装荷される，側面蓋を閉じ たあと，燃料送り込み機構によって燃料ピン束をせ九断 機本体部へ一定量押し出し，燃料ピン束が動かないよう にギャグで拘束したあと，せん断刃シリンダで駆動され る階段状のせ九断刃でせん断する。せ九断片はホッパ内 を落下し，下部に設置された溶解槽に投入される.

\subsection{3 溶解工程機器}

高速炉燃料再処理で用いる溶解槽には，軽水炉用とし て実績のあるバッチ型溶解槽の久点を克服した上で，さ らに小型で大容量の処理能力が求められる．初期の軽水 炬再処理や高速炬再処理で用いられているバッチ型溶解 槽は, 運転時のオフガス発生量の変動が大きく, オフガ 又処理設備が大型化する傾向にあるとともに，運転時間 がかかることから処理能力を上げるためには溶解工程の 全体的な大型化が必要であった。一方, 高速炉燃料再処 理では，使用済み燃料の特徴として高プルトニウム富化 度，高燃焼度化となることから，臨界管理，材料腐食等 の観点から使用睘境が厳しく制限される。このため，サ イクル機構ではこれらの課題を解決する新型溶解槽の開 発に着手した。

新型溶解槽の開発は，従来の平板型溶解槽 (バレル・ス ラブ型) の改良から始まり，その後，バッチ式に代わる連 続式のメリットが認識されるようになり，米国のオーク リッジ国立研究所（以下，ORNLと記す.）との日米共同研 究の中で回転円筒型の連続式溶解槽が選択され，コール

ドおよびウラン試験が実施された。

この回転円筒型連続式溶解槽は，連続的（もしくは間欠 


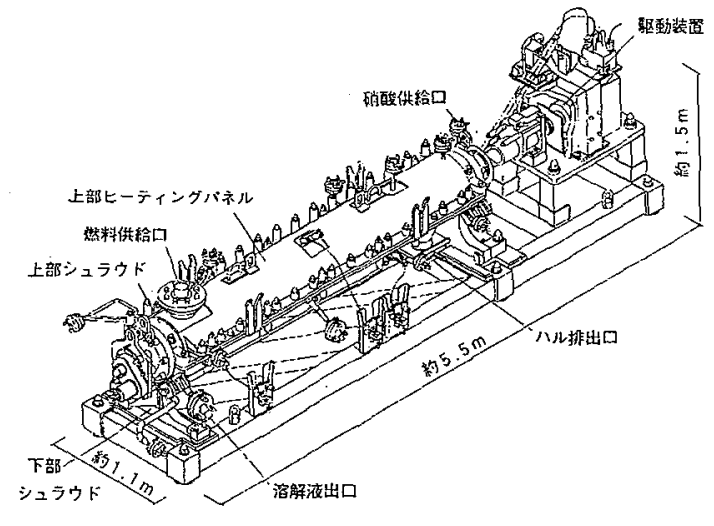

Fig.5 Continuous rotary dissolver

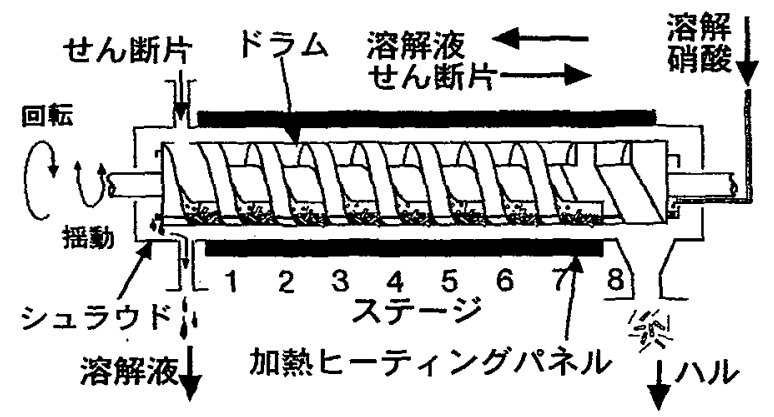

Fig.6 Schematic of continuous rotary dissolver

的）に装荷される使用済み燃料を，溶解用の加熱硝酸上 の交流接触により溶解し, プロダクトである溶解液と解 け残りのハルを連続的に分離し，回収することができる といつた特徵を有する機器である．RETF 用連続溶解槽 の概要を Fig.5, Fig.6に示す. RETF での処理能力につい ては, $10 \mathrm{~kg} / \mathrm{h}$ （金属ウランおよび金属プルトニウム換算）と 設定している．溶解条件は，これまでの軽水炬用溶解槽 の知見等から液温を $60{ }^{\circ} \mathrm{C} \sim$ 沸点, 硝酸濃度を $5 \sim 13.5 \mathrm{M}$ に設定している，臨界管理については，回転円筒の中心 軸の内部に中性子吸収材 $\left(\mathrm{B}_{4} \mathrm{C}\right)$ を配置し，形状管理と併 用することにより可溶性中性子吸収材等を使用せずに臨 界安全を担保することが可能である，材料腐食について は，チタン $5 \%$ タンタル（以下，Ti-5\%Ta と記す.）を採用 することにより，沸騰硝酸環境で高い耐食性を確保して いる．本溶解槽は，駆動部および部品点数を極力少なく し，溶解槽の構造をできるだけ単純化することにより， 機械的要因によるトラブルをなくしている.また，運転・ 保守性の向上の観点から，機内観察用としてファイバー スコープを用いた内部観察システムを開発した.

\subsection{4 清澄工程機器}

溶解掖中には, 固体状の不溶解成分（以下，スラッジと 記す、）が含まれている、スラッジは，燃料せ九断時に発
生する燃料被覆管のせん断片，燃料溶解時に発生する不 溶解残さ等である．高速炉燃料再処理では，燃料の高燃 焼度化に伴い，軽水炬燃料再処理に比べて数倍のスラッ ジ（不溶解残さ）が溶解液中に含まれる. スラッジは，次 工程の溶媒抽出工程において悪影響を及ぼすことから， これらを分離・除去するために清澄工程が設けられてい る.

せん断粉の量および粒径分布は，模擬燃料集合体を用 いたせん断試験結果から推定されており，高速增殖炉「も んじ的」炻心燃料では 1 体あたり約 $780 \mathrm{~g}$ 程度で, 粒径 は数 $\mathrm{mm}$ から数 $\mu \mathrm{m}$ の範囲である.不溶解残さについては, 主に高速実験炬「常陽」の照射済燃料を用いた溶解，抽 出試験等のデータから, 形状, 粒径, 発生量, 組成が推 定されており，高速增殖炉「もんじゅ」炕心燃料1体あ たり約 $850 \mathrm{~g}$, 粒径は $0.5 \sim 5 \mu \mathrm{m}$ 程度である.

清澄装置はとしては，大きく「遠心式」と「フィルタ 式」がある。これまでに「遠心式」として遠心清澄機, 「フィルタ式」としてパルスフィルタを製作し，評伍試験 を実施してきた. 機器の構造, 運転性, 保守性, 安全性, 分離能力, 処理能力, 使用実績および信頼性についての 比較結果, 並びに開発的要素, 廃枲物発生量の低減, 運 転性, 保守性を考虑して, 現在, RETF 用機器としては 遠心清澄機が選定されている.

遠心清澄機は, 溶解夜中のスラッジを遠心力によって 回転するボウル内面に捕集して清澄する．ボウル内に捕 集したスラッジは，高圧洗浄水でスプレ一洗浄し，洗浄 水とともに排出する，遠心清澄機の概要を Fig.7，Fig.8 に示す.

RETF仕様の定格回転数 $3000 \mathrm{rpm}$ 遠心清澄機の開発は, 昭和 53 年度より着手している. モックアップ試験機およ び遠隔保守用供試体を用いた清澄性能，洗浄性能，機械 的性能試験および遠隔保守性の检討を中心に実施し，次 工程の抽出工程への影響度を考慮して限界捕集粒径 1 $\mu \mathrm{m}$, 粒径 $0.85 \mu \mathrm{m}$ の粒子に対する捕集効率 $90 \%$ 以上を設 定している[1]. なお，目標限界捕集粒径を $0.5 \mu \mathrm{m}$ 程度と する高性能機（定格回転数 $6000 \mathrm{rpm}$ ）の開発も実施してお

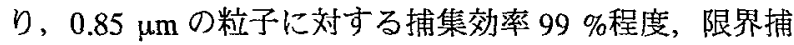
集粒径 $0.85 \mu \mathrm{m}$ を達成した[2]. また，運転・保守性の向 上の観点より，機内に捕集されるスラッジの特定箇所へ の偏析の有無およびスラッジの洗浄状況の確認を運転中 に把挃する手段として,ファイバースコープを用いた内 部観察システムを開発した。

\section{2 抽出工程機器技術}

PUREX 法を用いて高速炬使用済み燃料を再処理する 場合, 軽水炉然料に比べて使用済み燃料中の Pu 含有量が 多く，燃焼度が高いことから，臨界安全設計が厳しくな るととともに，溶媒劣化等の問題が梁刻化する傾向にあ 


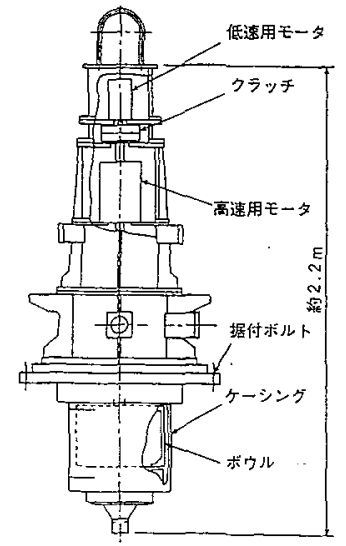

Fig.7Centrifugal clarifier

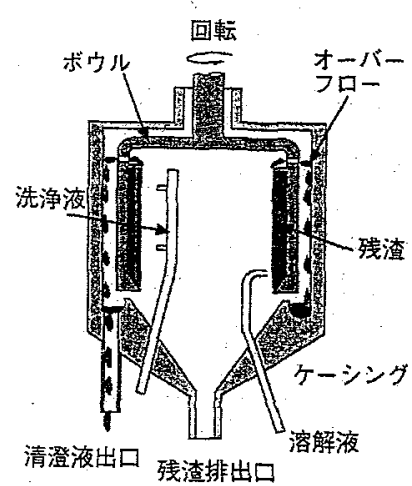

Fig.8 Schematic of centrifugal clarifier

万.

それに対し，遠心抽出器は，混合抽出を行った水相・ 有機相の分散相を，遠心力を用いることで短時間で分離 することができるといった特徵を有する機器であり，分 散相を重力で分離するミキサセトラやパルスカラムに比 ベて小型であり，滞留時間が短く，ホールドアップ量が 少なくなるため，上記課題の解決に有利である。

そのため, サイクル機構では遠心抽出器の開発を実施 している. Fig.9, Fig.10に RETF 用遠心抽出器の原理, 構造および試作器の外観を示す．図に示すように，遠心 抽出器は, 抽出分離を行うロータと, ロータを駆動する 駆動部，ロー夕を収納し夜の流路としての機能を持つ八 ウジングで構成される，ハウジングの供給口から供給さ れた，有機相と水相は，回転するロータと八ウジングの 閒の混合部で擋找混合が行われ，その間に抽出が行われ る.ロータ内の夜は，ロー夕入口部の径と, 出口部のせ きの径の違いに伴う避心場での傾斜のため, 下部から上 部へ流执る。して, ロータ上部で, 比重の重い水相は ロー夕外周部から, 軽い有機相はロータ中心部から分離 回収され，それぞれハウジングのコレクタへ排出される. 排出された液は，コレクタから，ロータのハウジング内

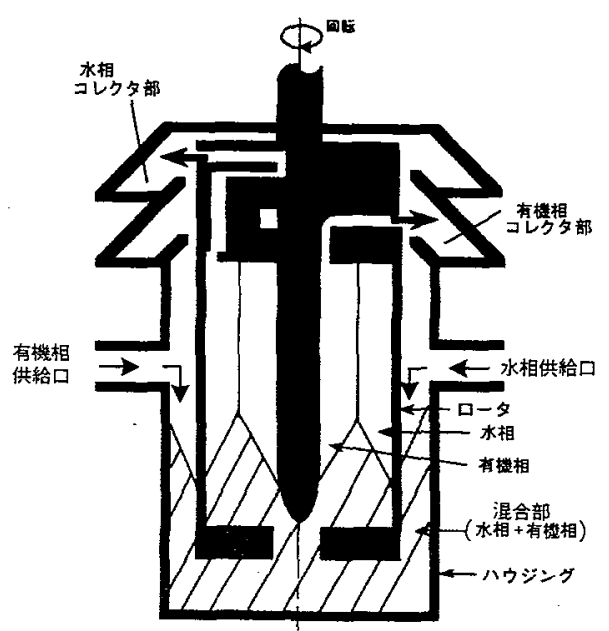

Fig.9 Schematic of centrifugal contactor

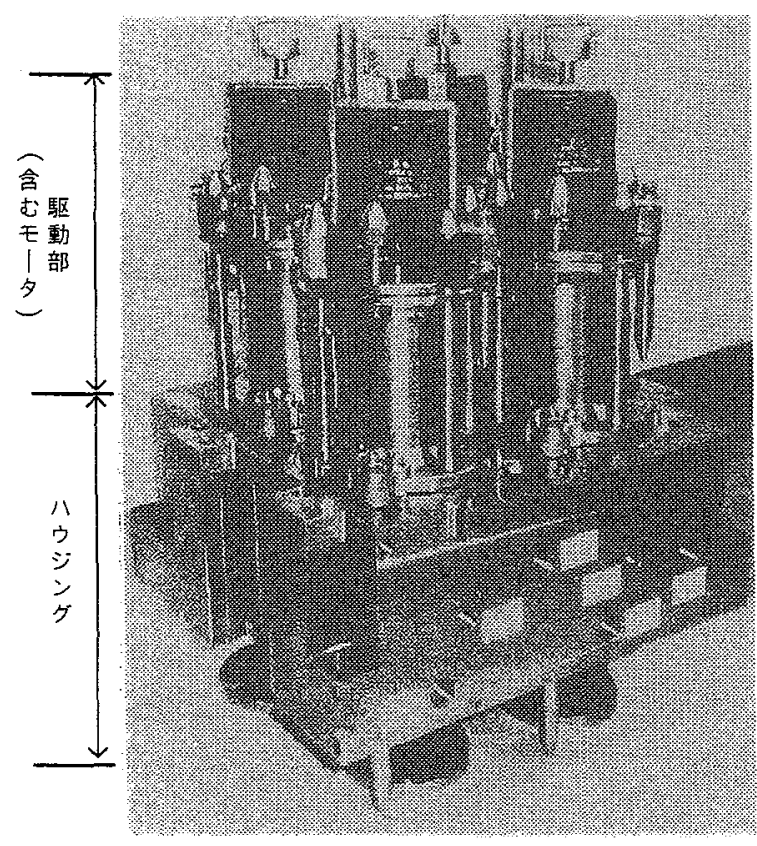

Fig.10 JNC type centrifugal contactor

を貫通する流路を通って隣接段へまたはハウジング外へ 送られる、なお，ロー夕停止等の異常時に備え，混合部 の最上部，コレク夕值下に隣接段へ接続されるオーバー フローラインを設けている.

遠心抽出器の開発は，現在 RETFでの使用を目標に開 発を継続しており，単機レベルの試験は終了し，RETF の設計条件を满足できる見込みを得た．また，遠隔保守 可能であることも確認している. なお, 遠心抽出器の抽 出性能に関しては，昭和 62 年から平成元年にかけ遠心抽 出試験装置（6段 or 10 段の多段システム）を用いたウラン 抽出試験および過渡特性試験を実施しており，段効率と して抽出の場合 $90 \%$ 以上, 逆抽出の場合 $85 \%$ 以上の值が 得られている[3].

一方, 溶媒洗浄工程等で水相と有機相との流量差が数 十倍に達する条件で, 使用可能な遠心抽出器として内部 


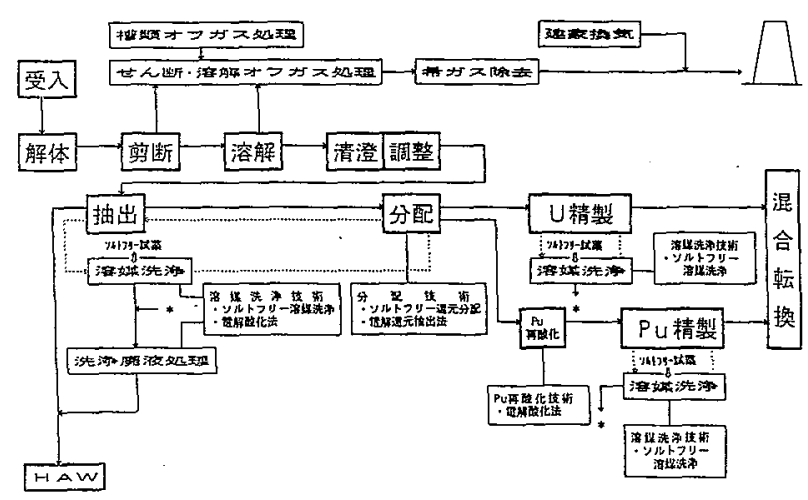

Fig.11 Diagram of reprocessing using salt-free method

Table 1 Advanced reprocessing using salt-free method

\begin{tabular}{|c|c|c|c|}
\hline & 分配工程 & Pu再酸化 & 溶媒洗浄工程 \\
\hline 從些プロ & $\begin{array}{l}\text { ウラナスに占的 } \\
\text { Pu/UO分離 }\end{array}$ & 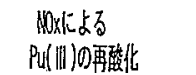 & 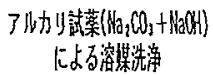 \\
\hline & 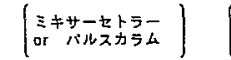 & 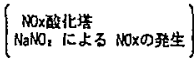 & (ミキサーセトラー) \\
\hline & ・ルルトフリー還元訪薬 & ，電确酸化法による & ・ソルトフリー榙 \\
\hline & 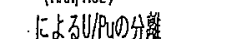 & 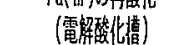 & 的酸上ラ早 \\
\hline \multirow{2}{*}{ 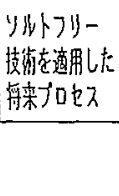 } & \multirow{2}{*}{ 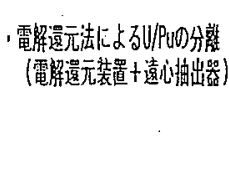 } & & 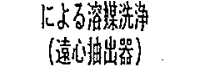 \\
\hline & & & 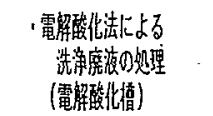 \\
\hline
\end{tabular}

循環型遠心抽出器を開発している.

現在，駆動部の耐久性試験を継続するとともに，実機 相当の多段で構成された遠心抽出器試駼装置で夜流動性, 抽出特性の確認等を実施する計画である.

\section{3 ソルトフリー技術}

ソルトフリー技術とは，「含塩廃棄物発生の低減」を目 的とした技術であり，以下に示すような基本的考え方に 基づき再処理プロセスへの適用を検討してきた.

ソルトフリー技術では，従来技術と同等以上の性能を 担保しつつ, 工程からの含塩廃棄物発生量の抑制, 低減 および試薬添加量の削減を図る．また，本技術では，コ ンパクト化および工程の短縮化が図れるプロセスを採用 するとともに，運転の簡素化を図る．

Fig.11, Table 1 にソルトフリー技術の工程全体にわた る適用先とそれらの内容を示す，上記の考え方を満足す る方法として, 容易に気体にまで分解可能な試薬 (ソルト フリー試薬）の採用（溶媒洗浄試薬やPu 分配試薬に適用）や 電気化学的手法を用いた Pu の還元および試薬の分解が
あげられる。

サイクル機構では, これまでにソルトフリー溶媒洗浄 試薬（炭酸ヒドラジン, シュウ酸ヒドラジン）を用いたソル トフリー溶媒洗浄工学試験, ソルトフリー還元試藥（硝 酸ヒドロキシルアミン (以下，HAN と記す.)) を用いた $\mathrm{Pu}$ 分配試験, 電解酸化槽を用いた電解酸化工学試験を奏施 してきている[4,5].

これらの試験成果をふまえ，以下の技術を RETF の設 計に反映してきている.

・ソルトフリー還元試薬（HAN）による U/Puの分配

・電解酸化槽による $\mathrm{Pu}(\mathrm{III})$ の再酸化およびりルトフリー 還元試薬の分解

・ソルトフリー溶媒洗浄試薬（炭酸ヒドラジン, シュウ酸七 ドラジン)による溶媒洗浄

・電解酸化槽によるソルトフリー洗浄試薬の分解

\section{4 材料技術開発}

サイクル機構における再処理分野の材料技術開発住, 東海再処理工場が直面した再処理機器の應食故障の原因 究明という形で開始され, 以後, プラントの安全性向上 および稼働率維持の観点から重要な基盤技術開発として 位置付けられた[6].

現在, 我が国の再処理施設における機器材料の多くに はステンレス鋼が適用されている. ステンレス鋼は一般 に硝酸環境中で不㗢態を形成し，優れた耐食性を示すこ とから, 再処理分野のみならず硝酸化学プラントで沉用 される優秀な材料である.しかし，操業初期に生じた東 海再処理工場の腐食故障事例が示すように，ステンレス 鋼の過不動態に相当する強酸化環境では粒界侵食を伴っ て腐食が加速される．そこで腐食故障への対策として， 強酸化環境中でさらに耐食性に優れた Ti-5Ta や Zr の適用 技術開発が行われ，材料側および環境側から機器の長寿 命化に向けて腐食データの収集が進められてきた．その 結果, Ti-5Ta や Zr はすでに軽水炉用再処理施設の装置材 料として適用されてきており，実用化に成功している.

中でも高速炬燃料再処理用の材料技術開発については, 主に RETF 用の装置材料に関する設計デー夕を取得する ために，実溶解液中での腐食挙動や軽水炉の場合よりも 腐食への影響として懸念されるプルトニウムや放射線等, 高速炬燃料に特徵的な亜境側の简食因子に着目して, 腐 食データの収集および機構解明に取り組えできた。

高速炬燃料溶解液中での各種材料の腐食挙動について は，Fig.12 に示すようにオーステナイト系ステンレス鋼 は純硝酸環境亡比較して, 腐食が加速される傾向を示す; 一方, Ti 系材料や $\mathrm{Zr}$ 溶解液中においても優れた耐食性 を示した[7]. さらに硝酸プルトニウム溶液による評価結 果との比較から，燃料溶解液中のプルトニウムがステン レス鋼の主な鹰食促進要因であることが示唆された[8]. 


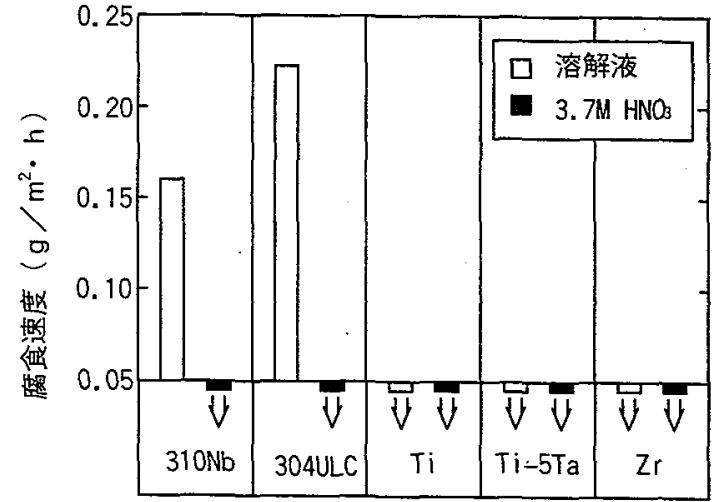

Fig.12 Corrosion rates in pure nitric acid and dissolver solution

放射線の影響については，高燃焼度による核分裂生成物 の発生量増大を考虑し, $\gamma$ 線を対象に材料腐食への影響 について調査してきた。 その結果, 強酸化環境条件では 生成した $\mathrm{Ru}, \mathrm{Cr}$ の高次イオンが $\gamma$ 線により還元されるた め，ステンレス鍼の腐食は一般に抑制される万向に作用 することが示唆された。

このように高速炬燃料再処理環境はプルト二ウム量の 增大等により, 軽水炉環境よりも一層腐食環境が過酷に なるものと予想されるが，軽水炉環境で蓄積された知見 を生かしつつ, 高速炉燃料特有の腐食因子を踏まえた技 術開発が進められている。

\section{5 遠隔技術}

サイクル機構では, 当時計画されていた高速炉燃料再 処理パイロットプラントにおいて，大型セルによる嗃隔 保守方式の概念を採用することとし要素技術の開発に着 手した。

大型セルによる遠隔保守方式は放射性物質により污染 される保守対象機器をラック(規格化されたフレーム構 造体)の中に收納した上で, クレーン等の大型の保守機器 が配置されている大容積のセルに設置し, 電気式マスタ ースレーブマニプレータ（以下, EMSM と記す.) やクレー ンで保守作業等を行うというものである.

昭和 57 年度よりサイクル機構版 EMSM となる両腕型 バイラテラル (力言還機構) サーボマニプレータ (以下, BSM と記す.）の開発[9]に着手し, 翌昭和 58 年 8 月に試 作 1 号機の製作を完了した. 試作 1 号機は制御の関係上 スレーブアームの自重補償を最小限とするため, 时が外 側を向いた形状のプレーナ型を採用した。この形状は保 守対象機器に対して側面からのアクセスに適しているが, ラックへのアクセスには不向きだった.

このため, 昭和 60 年度から試作 2 号機の開発に着手し た. 比較的高出力で，かつ速い動作速度を必要とする肩
関節および时関節については，エルボダウン式モータ集 中配置トルクチューブ駆動方式を採用しラックへのアク セスを考慮した。

さらに, 昭和 62 年度からは, 平成元年度に東海事業所 のガラス固化技術開発施設（以下，TVF と記す.) へ BSM が導入されるまでに，その機能向上を目的とした改良を 実施した[10].

マスターアーム操作力低減に関しては, 試作 2 号機で はマスターアームの反力 (=出力) を最大 $4 \mathrm{~kg}$ で設計して いるが，ここでは $1 \mathrm{~kg}$ 程度あれば遠隔操作を行う上で支 障ないことを確認し，設計に反映した。

バイラテラル性能の向上に関しては，試作 2 号機では マスターアームの自重補償に電気バランス方式を採用し ていたことから，自重補償分，モー夕出力が分散し，モ 一タ出力が有効に活用されず，その分バイラテラル性能 を低下させていた．そこで，マスターアーム操作力の低 減に加えて，改良型マスターアームの機械設計において は低摩擦モータと小型ギアを採用することとした：この 結果，マスター側の不感带を低く抑えることができ，ま た, マスターアーム操作力の低減と相まって, さらに, 各制御ゲインを高めることで, バイラテラル性能の向上 を可能とした[11,12]. 改良後の試作 2 号機外钼を Photo.1, Photo. 2 に示す.

耐放射線性高品位 TV システム（HDTV）については目 標としていた $2.58 \times 10^{4} \mathrm{C} / \mathrm{kg}\left(10^{8} \mathrm{R}\right)$ の耐放射線性を有す

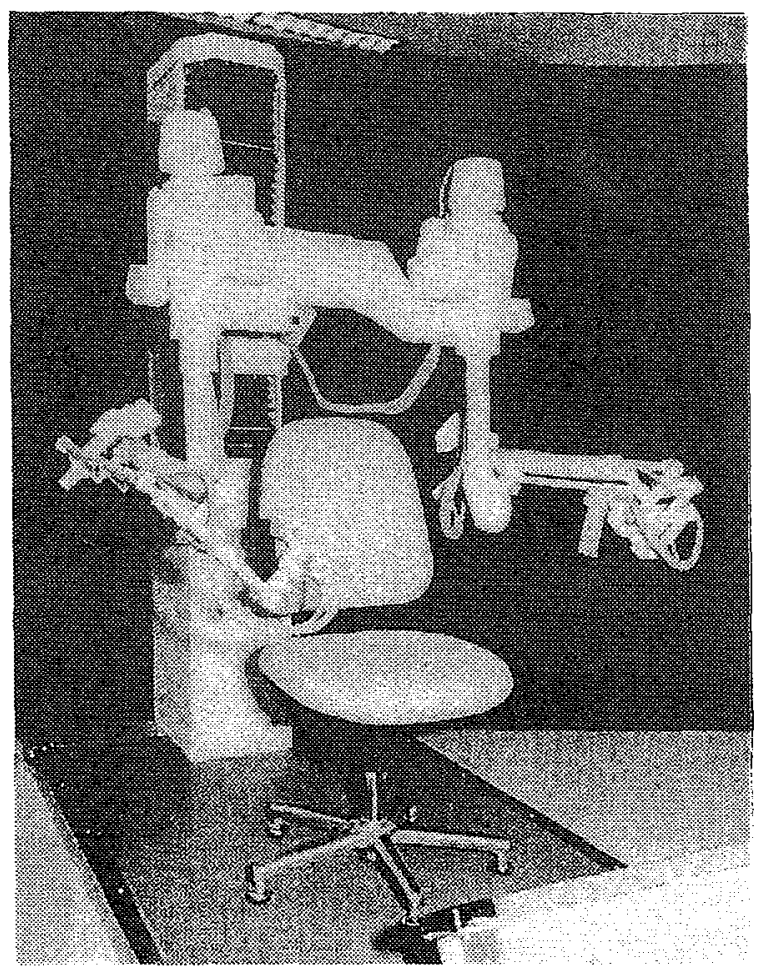

Photo.1 BSM master arms 


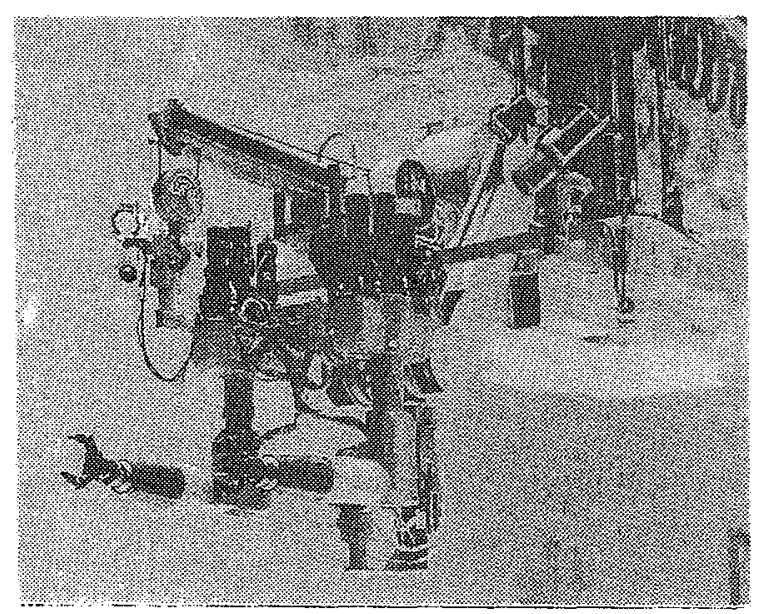

Photo.2 BSM slave arms

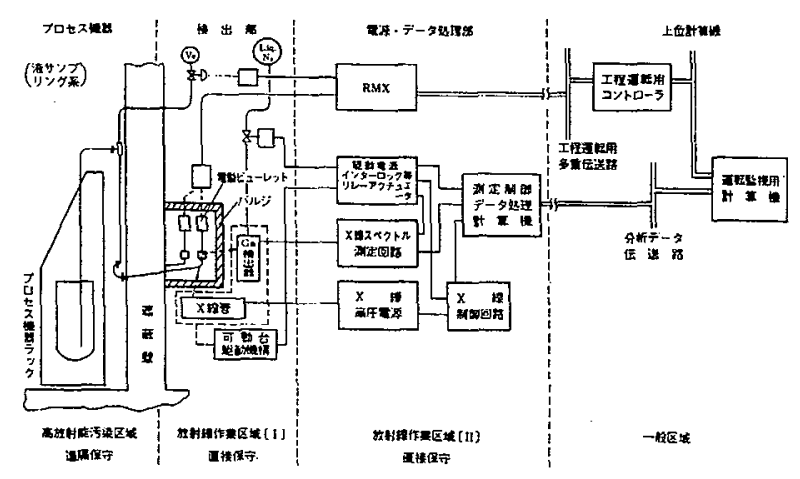

Fig.13 In-line K-edge/XRF analysing system

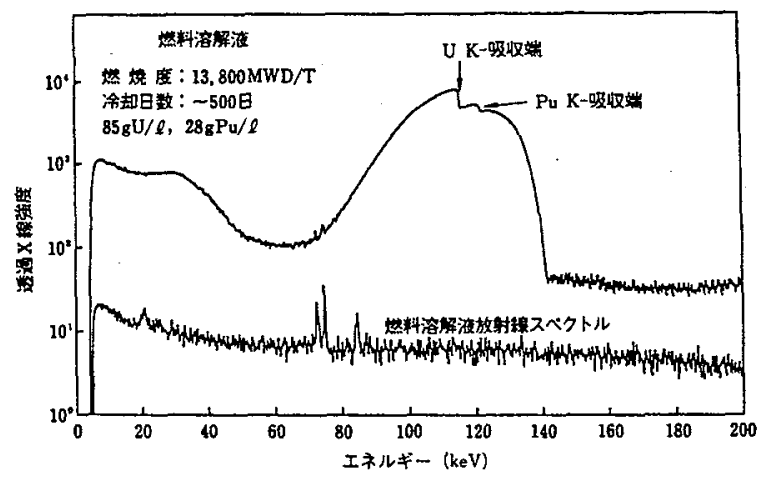

Fig.14 K-edge and X-ray spectrometric data for dissolver solution

る水平解像度 700 本の HDTV システムを昭和 62 年度に 開発し，TVF 用 BSM の左肩カメラに採用した。

これらの成果のほとんどは RETFにおける遠隔保守設 計に反映されている.

\section{6 分析技術}

核燃料再処理プラントにおいては，工程管理，計量管 理，製品管理を目的として分析を行うが，その分析項目 は数百種にもおよび，多大な分析設備と作業員を必要と し,プラントの運転コストにも影響を与える.このため， 分析の効率化，作業員の被代くの低減化等，分析業務の 合理化，省力化を目標とした技術開発を行ってきた。

\subsection{1 インライン分析技術開発}

インライン分析法は，分析の省力化，迅速化，被ばく 低減化および発生廃棄物の低減化を達成するための理想 的な技術であり，経済効果も期待できる.

これまでに $\alpha$ モニタ，K 吸収端 $\mathrm{Pu}, \mathrm{U}$ 濃度モニ夕，フ オトメータ等多くのインライン分析技術（Fig.13, Fig.14） について, システムの設計研究，Pu，U確証試験，遠隔 保守試験を実施しており， $\alpha$ モニタやフォトメータの開 発技術は，RETF のインラインモニターに採用されるこ とになっている。

これ以外にも，K 吸収端 $\mathrm{Pu}, \mathrm{U}$ 濃度モ二夕,フローク 一ロメトリ等は実用段階に近いレベルに達している技術 であり，この測定原理をオフライン分析へ応用をすれば 再処理プラントにおいても十分に利用できる技術となる。

\section{6 .2 オフライン分析技術開発}

オフライン分析技術開発は，既存の分析手法や分析装 置を改良し，セルやグローブボックスの作業環境に適合 させる技術開発であるため，プロセス条件に左右される ことなく分析側の要求で開発を進めることができる.

これまでに実用化あるいは設計に反映されたオフライ ン分析技術には, セル内操作型プラズマ発光分析装置, 劣化溶媒分析装置等があり，その開発成果は RETF 等奏 施設の分析設備設計に反映されている. また, 全自動滴 定分析装置など開発を継続している技術もあり，今後の 展開が期待される。

\section{6 .3 今後の展開}

これまでの分析技術開発の目標は，プロセス側および 分析側双方の二ーズを考慮したプラント運転の合理性, 経済性, 分析作業の省力化を狙ったものであり，今後も その基本は不変である. しかし，今後住前記目標を堅持 しつつ，さらに経済性を重視するとともに，MA 核種分 析の高感度, 高精度化, 迅速化, 化学構造解析技術の確 立など，新たなプロセス研究に備えた研究開発支援型の 分析技術開発を進める. また, 先進再処理技術として開 発を進めている乾式再処理に関するプロセス研究に備え， MOX, 溶融塩など固体分析に関する分析測定技術, 前処 理技術，分析廃棄物の処理技術を確立していく。

\section{7 プラント設計技術}

サイクル機構においては，これまでの研究開発および 日米協力の結果を踏まえて高速炉燃料を用いた試験を目 


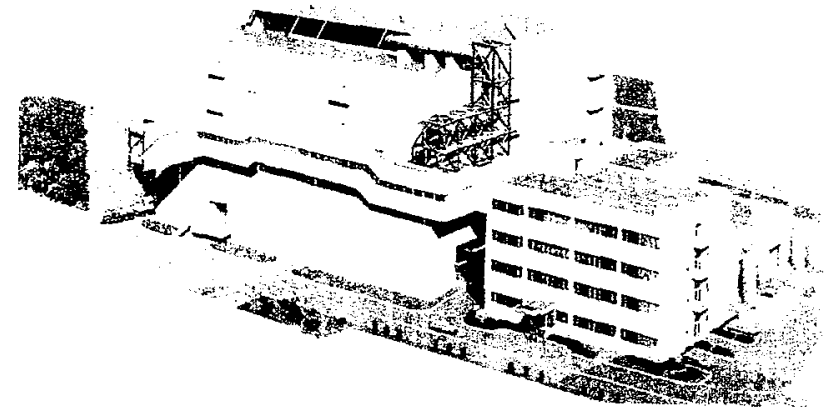

Fig.15 View of RETF（computer aid 3D graphic）

的とした RETF の概念を構築し，それを基本として設計， 建設を行うことにより，プラント設計技術の開発を進め てきた (Fig.15参照).

RETF は, 高速增殖炬「もんじゅ」の炬心燃料・ブラ ンケット燃料，高速実験炬「常陽」のブランケット燃料 を用いて, 高速炉燃料湿式再処理機器・プロセスのホッ 卜工学試験を行うための施設であり, 解体試験設備, せ 九断試験設備, 溶解試験設備, 清澄試験設備, 抽出試験 設備, 溶媒洗浄試験設備等を有するものである.

RETF では，大型遠隔保守セル方式を採用し，上記の 試験設備を Fig.16に示す試験セルと呼ぶ大型セルに収納 することとした．さらに主要機器を金属フレームで構成 された移動可能なラック上に配置することで，機器の交 換・変更が比較的容易に行える設計とした．保守につい ては試験セル内での両腕型マニピュレータ等での遠隔操 作による保守, 機器の取り外しおよび投出ができ，さら に保守用のセルへの搬出後, 直接保守も可能な設計とし た。

なお，大型セルの採用に伴いセル換気風量を低減させ るため，セル内の温度管理を専用のセル内冷却器で行う 低風量換気を採用し，さらに試験セルの排気は槽類オフ ガス処理設備て処理することとし，セル内活染が生じて も環境への放出放射能が低減できる設計とした．

安全設計としては，臨界，火災・爆発の防止，遮へい， 耐震，耐压等を考慮した設計としている．特に臨界安全 については，基本的に形状管理および質量・濃度管理を 組み合わせることにより臨界安全を確保し，臨界管理方 法の異なる機器への溶液の移送については, 施錠弁を設 け誤移送を防止する設計とした。

火災・爆発の防止については, これまでの再処理施設 の設計と同様に，有機溶媒を引火点未满で取り扱うとと もに，着火源を排除し，蒸発缶においてはTBP の急激な 分解反応を防止するため加熱蒸気温度を制限する設計と

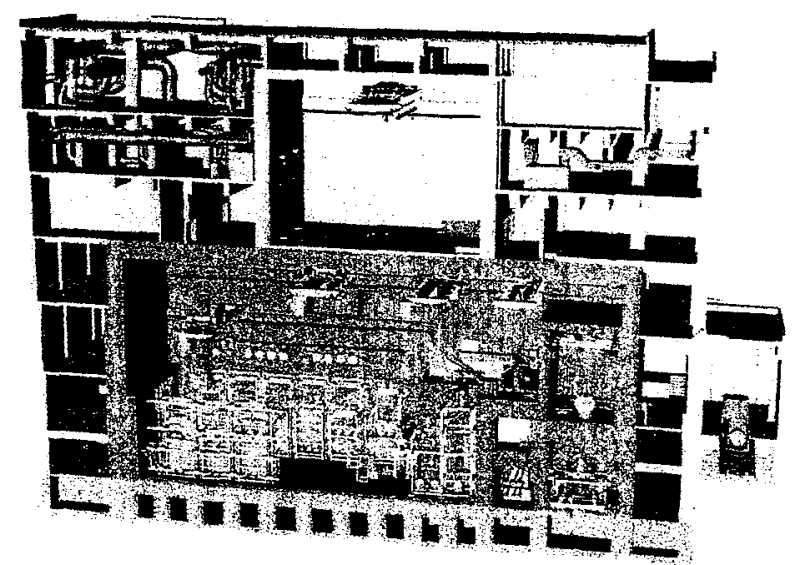

Fig.16 View of RETF main cell

した.

また,これら安全設計のため, 線源計算, 臨界計算, 遮へい計算など, 最新の計算コードの整備を行っている.

さらに施設の安全評価については, 異常時影響評価に 基づき運転時の異常な過渡変化 (AT), 異常な過渡変化を 超える事象（BAT）の評価を実施し, 安全性を確認した. なお，本施設は平成 7 年 1 月に着工以来, 銧意建設を 進めてきたが, 平成 9 年 3 月に発生したアスファルト固 化処理施設の火災・爆発事故を契機にサイクル機構とし て安全対策に重点を置いた事業展開を図ることから予算 の見直しを行い，RETF 建設工事を一時中断することと なった.さらに，サイクル機構の中長期事業計画ではこ れまでの高速增殖炬サイクル技術開発の進め方を見直し， その後の RETF 計画を作成することとなっている.

\section{4 先進再処理技術開発の現状}

\section{1 簡素化 PUREX プロセス開発}

次世代の核燃料サイクルとして，サイクル機構は経済 性に優れ環境負荷低減および核不拡散性も考慮した先進 核燃料サイクルを提案している[13].これは, 現行の PUREX プロセスをより簡素化，最適化することにより， 建設コストおよび使用試薬量を低減し(経済性)，また分 離プロセスから発生する廃棄物量を低減するものである (経済性，環境負荷低減)，

PUREX プロセスの簡素化をさらに進めるための条件 として, PUREX プロセス製品の低 DF 化が提案されてい る. 現行の PUREX プロセス製品に比べてどの程度の低 DF 化が可能であるがついて，燃料製造および炉心設計 之密接な協議・調整が必要であるが，低 DF 化を前提条 件とすることにより，除染工程の短縮と製品の精製工程 の削減が期待される (経济性)。さらに, 製品の低 DF 化 は，核分裂性物質へのアプローチを困難にすることを意 味する(核不搪散性)。 
分配工程におけるU 洗浄工程の削減およびフローシー ト条件の最適化により，燃料製造に都合の良い比率の $\mathrm{U} /(\mathrm{Np}) / \mathrm{Pu}$ 混合製品が得られるようなプロセスも検討し ている.これにより工程が簡素化され (経済性), また $\mathrm{Pu}$ を単独で扱うことのないプロセスとすることができる (核不拢散性).

高レベル放射性物質研究施設（以下，CPF と記す）では， 簡素化 PUREX プロセス開発として, U・Pu 共回収並びに $\mathrm{Pu} \cdot \mathrm{Np}$ 共回収型のフローシート検討のためにホット試 験を実施してきた。 $\mathrm{U} \cdot \mathrm{Pu}$ 共回収は分配工程に洗浄溶媒 を供給しない方法を採用した.ここで, Pu逆抽出液の流 量を調節することにより，Pu 製品中の U と $\mathrm{Pu}$ の比を 適宜調整できることを確認した. また，Np 回収方法と して, 工程内の亜硝酸濃度を低下させることにより，Pu 製品に移行させる方法を検討した[14]. 具体的には, フィ 一ド液中の $\mathrm{Pu}$ の一部を $\mathrm{Pu}^{6+}$ に酸化し，共存する亜硝酸 濃度を低下させる方法についてホット試験を実施した。 今後, プロセスフローシートの最適化および分離メカニ ズムなどに関連した検討を深める必要があるが，基本的 には本法により Np の共回収が可能であることを確認し た.

\section{2 晶析技術}

高速炉燃料サイクルにおける将来の湿式再処理技術で は，低除染燃料の利用が成立することを前提に，工程を 簡素化し Pu を一部の U とともに回収することを指向し ており, PUREX 法の改良の他にイオン交換法, 炭酸沈殿 法，晶析法等の候補が挙げられる。このうち，晶析法は PUREX 法と組み合わせることにより廃棄物低減と経済 性向上の可能性をもっている[15].

晶析法とは, 対象となる溶液中の目的成分濃度を過飽 和とすることにより，目的成分を結晶として回収する方 法である．過飽和溶液を得るには，水分を蒝発させて目 的成分濃度を上げる, あるいは溶液を泠却し溶解度を下 げる等の方法がある：溶解度の温度依存性が高い硝酸ウ ラニル-硝酸溶液の系に対しては, 冷却晶析が適用される.

原子力分野において晶析法が実際に適用され，プラン トとして操業された例はないが, 西独 Kernforschungszentrum Karlsruhe（現在, 独 Forschungszentrum Karlsruhe) お よび東京電力(株) /三菱マテリアル(株)において U 精製工 程への晶析法適用が検討された例がある[16,17].

溶媒抽出工程に供給される使用済み燃料溶解液には, U が金属元素として最も多く含まれている．ここで溶媒 抽出工程に先立ち U を粗分離できれば, 溶媒抽出工程へ の供給液量や必要な試薬を大幅に削減することができる. 晶析法は不純物を含む系から多量成分を結晶として分離 回収することができる方法である，これを燃料溶解液に 適用した場合にはUのみを分離回収することができる。

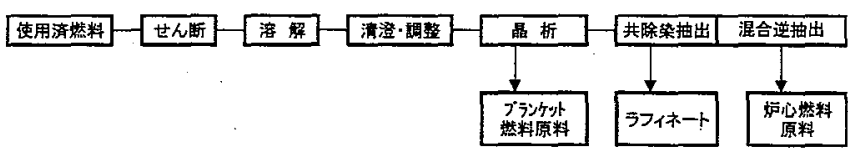

Fig.17 Process diagram for crystallization

さらに晶析工程でのU の回収率設定によっては U, Pu 混 合製品の $\mathrm{Pu}$ 富化度の調整も期待できる.

Fig.17に晶析法を導入した場合の再処理工程概念図を 示す. 晶析法導入プロセスは, せん断工程, 溶解工程, 清澄工程, 晶析工程, 溶媒抽出工程からなる. 晶析にお いて溶液の温度を低下させることによりUの大半を結晶 として回収する. 晶析工程の製品はブランケット燃料の 原料とする. 晶析工程後の溶液は母液と呼ばれ, 溶媒抽 出工程へ供給する：U，Pu の逆抽出には希硝酸を用い， $\mathrm{U}, \mathrm{Pu}$ を共に回収する. 回収製品は炬心燃料の原料とする. 従来の PUREX プロセスに存在した U 逆抽出工程は不要 となる $[18]$.

晶析プロセス開発のためには U, Pu の溶解度に関する 基礎デ一夕は必須である. そこで, 高ウラン濃度溶液等 を用いた基礎試験を実施し，基礎デー夕の採取，晶析条 件の確認を行っているところである.

\section{3 マイナーアクチニド (MA) 分離技術}

TBP（Tri-Butyl Phosphate）はAm 等 3 価 MA の抽出性に 劣るため, TBP 以外の抽出剤を用いた 3 価 $\mathrm{MA}$ 分離技術 が数多く開発されてきた.このうち主な分離技術として， 二座配位型中性抽出剤を用いたプロセス(TRUEX プロセス [13], DIAMEX プロセス[19])や TBP よりも電子対供与性の 大きいホスフィンオキシドを用いたプロセス（TRPO プロ セス[20]），酸性抽出剤を用いたプロセス（4 群分離プロセス [21]）などが提案されている.いずれのプロセスも 3 価 MA とランタニド元素の分離が大きな課題として挙げら れている.ランタニド元素の中には, 中性子吸収断面積 が大きく，いわゆる中性子毒として作用するものがある ため, いかにランタニド元素をアクチニド元素から分離 するかが重要となる.

サイクル機構では, TRUEX プロセスをベースしした MA 分離技術開発を中心に試験研究を進めてきている. コールド試験では, 主に FP 元素に注目した試験を, トレ 一サ一試験では, Np や Pu の分配挙動および Am/Eu 分離 挙動等について，バッチ法による基礎試験を，ホット試 験では CPFにおいて各種基礎試験成果の確証を行うため の向流多段基礎試験等を実施した。これまでのところ, 高レベル廃液（濃縮操作なし）から直接 3 価アクチニドを 抽出できることを確認している. 一方で, ランタニド元 素の 3 価 MAからの分離が困難であること, 抽出キャパ 

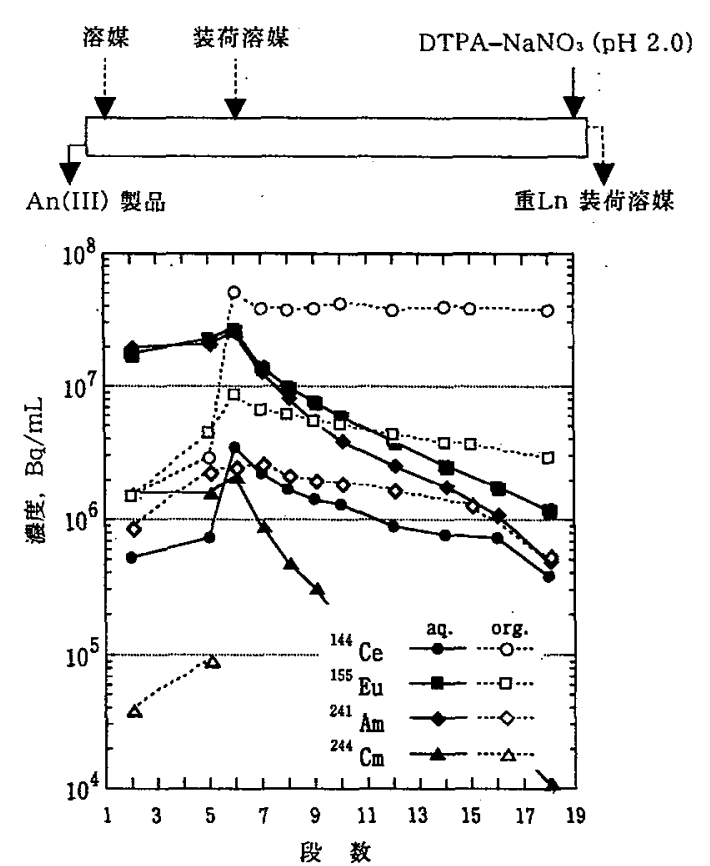

Fig.18 Stage profiles of major nuclides in the actinide(III) stripping process

シティがあまり高くないことなどの課題を摘出してきた これら摘出課題のうち，3 価 MA とランタニド元素の分 離については，アミノポリ眽酸を用いた分離法 (SETFICS 法)などを検討してきており,これまで DTPA（Di-ethylene Tri-amine Penta-Acetic acid）を利用し，実液を用いた向流連 続試験による分離性能の確認まで実施している (Fig.18) [22]. 上述した分離法では，3 価 MA とランタニド元素の 粗分離を行う. 次のステップとして, 3 価 $\mathrm{MA}$, 特に $\mathrm{Am}$ を単離するため, Am を高原子価に酸化したのち，炭酸 塩沈殿法あるいは溶媒抽出法により他の 3 価金属と分離 する方法の開発研究を進めている.

\section{4 乾式再処理技術}

乾式再処理技術の研究開発は, PUREX 法に代表される 湿式再処理法之同時期に始められたが，もともと金属燃 料に使用する金属ウランの精製法とその再処理方法とし て研究されており, 研究開発の中心が酸化物燃料に移る にしたがって縮小されていった.

しかし，近年，より高い経済性，環境負荷の軽減，核 不抎散性の点で湿式再処理法に比べて優位となる可能性 を有する乾式再処理技術が注目され, 将来湿式法と比較 評価を行うことを目標にサイクル機構においてもその研 究開発を加速してきた.

サイクル機構の開発目標は実用性の高い酸化物燃料の リサイクルを実現することである.このための乾式プロ セスとして, 米国ハンフォード研究所および露国原子炉
科学研究所 (RIAR) 等で開発された「酸化物電解法」 [23,24] を改良したプロセス（Fig.19）を基本プロセスとして研究 開発を進めている. また, これと平行して，米国アルゴ ンヌ国立研究所および（財）電力中央研究所（以下，電中 研と記す.) 等で開発が行なわれてきた「金属電解法」 [25] を基本プロセスとして，「還元工程」(酸化物を金属に転 換する）と「酸化工程」(得られた金属を酸化物に戻す)を 付加したプロセス（Fig.20）について, 電中研との共同研 究により，東海事業所 CPF でのプルトニウムを用いた試 験を実施することとしている.

「酸化物電解法」に関しては, 平成 11 年度から研究 開発に着手し，実験的手法によるウランを用いた溶解お よび電解試験を計画している. また，本方式の最も大き な課題の一つである電析 $\mathrm{UO}_{2}$ からの貴金属 $\mathrm{FP}$ の分離に 関する試験を実施し, 新しい分離方法の検討を進めてい る. 一方, 本方式について先行して研究開発を進めてい る RIAR との共同研究を行うべく調整を実施している.

また，「金属電解法」をベースとする方法については， 平成 6 年雾围気制御グローブボックスを導入し, $\mathrm{Ce} や \mathrm{Y}$ を用いた試験によって原理確認, 試験技術習得を目的に 研究を開始した. その結果, 電解析出の基本原理の確認 を行うとともに，㙁化物分解時の発生塩素挙動等の知見 が得られた。一方, ウランを用いた試験は本研究開始時 の方針に従って, 酸化物燃料の ANL プロセス適用に必須 の「還元」と「酸化」プロセスの可能性の確認を行った. 特に「酸化」プロセスについては溶融 Cd 中にウランを溶 解して酸化する独自のアイデアに基づく実験を行い, 生 成物が $\mathrm{UO}_{2}$ だけが優先的に生成することを見出した. こ の手法は高温を要する塩蒸留工程を省くことを可能にす ることで意義が有る.

\section{5 再処理技術開発の当面の進め方}

再処理技術の今後の開発は，これまでの再処理技術開 発の単なる延長上としてとらえるのではなく, 安全性, 経済性向上, 資源の有効利用, 環境負荷低減, 核不拡散 抵抗性の向上等, 社会の多様なニーズに適合できる先進 的リサイクル技術として開発していくことを強く要望さ れている.また，国内外の機関とより一層協力して開発 していく必要がある.

具体的には，軽水炉と比肩する経済性を確保する上で 有望と考えられる FBR サイクルの候補概念を具現化し， 実用化に向けた開発シナリオを策定することおよび工学 的試験も含めて技術的成立性を確認して整合性を図った システムの構築を目指した開発をおこなうことであり， 湿式法, 乾式法等について, 基礎デー夕を取得しつつ, かつ, 社会のニーズへの適合の下に絞り込みを行いつつ システムの構築開発を進めていく． 


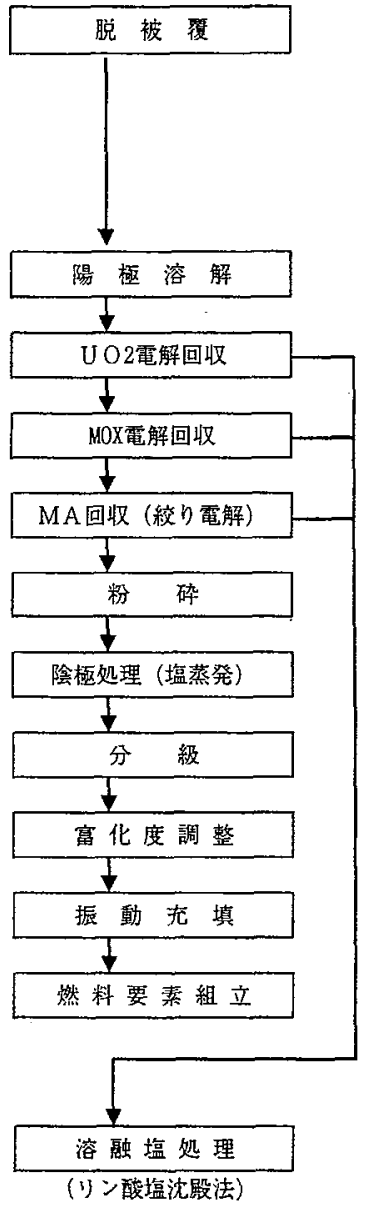

Fig.19 Oxide fuel electrowinning process (includes fuel fabrication)

湿式再処理法については，従来の湿式 PUREX 工程を 経済性の観点から見值し，低除染性を許容した簡素化 PUREX 工程／燃料製造一体化のプラント概念の具体化, プラント規模，TRU 回収，窒化物燃料対応性等，経済性 に影響を及ぼす因子の定量的な評価，プロセスやプラン ト設計・評価手法に関する整備を進める.

乾式再処理については，高温電気化学法をべースとす る改良 RIAR 法および改良 ANL 法,さらにはフッ化物揮 発法の 3 方式について，それぞれのプラント概念を構築 し，主として経済性の観点から評価を行う，また，湿式 法のプラントと併せて，経済的な競争力について比較・ 評価を行うものである.

\section{参考文献}

[1] 安隆己 他: 高速遠心清澄機の開発. 日本原子力学会 1991 年 春の年会, 近畿, 3 月 28〜30日, M1 (1991).

[2] 小島久雄: プルトニウムの利用技術の現状と課題 -

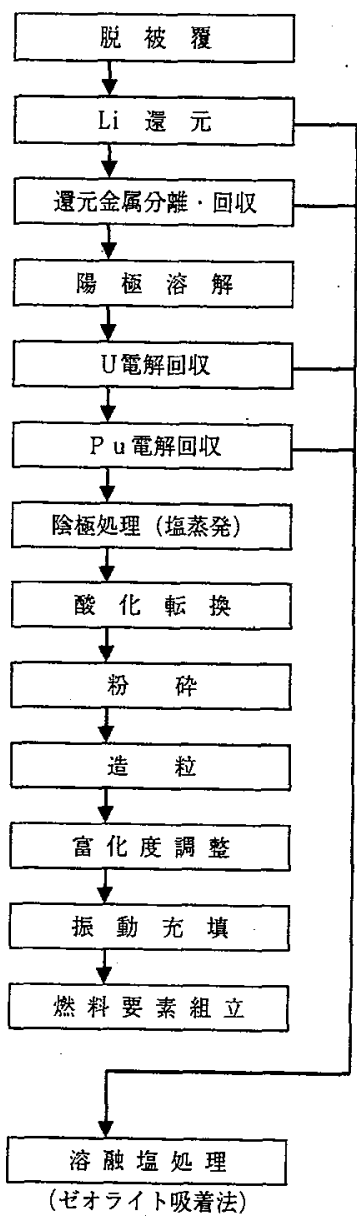

Fig.20 Metallic fuel electrorefining process with lithium reduction and fuel oxidation (includes fuel fabrication)

使用済み燃料の再処理 - 高速炉再処理 - . 原子力工業 第 40 巻,第 1 号, 37-42 (1994).

[3] Takeda,H. et al. : Development of a centrifugal contactor. ISEC'90, July 16-21, 112 (1990).

[4] 鷲谷忠博 他: ソルトフリー電解酸化槽工学試験. 動 燃技報 83,55-61 (1992).

[5] Ozawa,M. et al. : Mechanism for solvent cleanup process using solt-free reagent. RECOD'91, April 14-18, II, 1134-1139 (1991).

[6] 武田誠一郎 他: 再処理分野における材料技術開発の 現状。動燃技報 67, 64-75 (1988).

[7] 武田誠一郎 他: FBR 使用済み燃料溶解液中での各種 金属材料の耐食性. 日本原子力学会誌 36, 146-157 (1994).

[8] 武田誠一郎 他: 硝酸プルトニウム溶液での各種金属 材料の耐食性. 材料と環境 44, 24-29 (1995).

[9] 樫原英千世: 核燃料サイクル施設用遠隔保守技術の 開発。動燃技報 49,61-75 (1984).

[10] 藤田雄二 他: 両腕型サーボマニプレータの操作性 
改良. 動燃技報 68, 74-79 (1988).

[11] Koizumi,T. et al.: Remote maintenance test of two-arm bilateral servo-manipulator system. 37th Conference on Remote System Technology, 129-135 (1989).

[12] 川妻伸ニ 他: サーボマニプレータの操作性に関す る考察. 計測自動制御学会 第 32 回学術講演会予 稿集, 251-252 (1993).

[13] Horwitz, E.P. et al.: The TRUEX process - A process for the extraction of the transuranic elements from nitric acid wastes utilizing modified Purex solvent. Solvent Extr. Ion Exchange 3, 1\&2, 75-109 (1985).

[14] 根本慎一 他: 高速炉燃料再処理での $\mathrm{Np}$ と $\mathrm{Pu}$ の共 回収. 動燃技報 99,87-92 (1996).

[15] 山名元 他: 先進的 MOX 燃料リサイクル技術開発. エネルギーレビュー 第 16 巻, 第 4 号, 12-17 (1996).

[16] Henrich, E. et al.: Combination of TBP extraction and nitrate crystallization for spent nuclear fuel reprocessing. I. Chem. E. Symposium Series No.103, 191-205 (1988).

[17] 倉嶋昭弘 他: 再処理工程における晶析精製法の検 討[VI]. 日本原子力学会 1992 年秋の大会, 名古屋, 10 月 20〜23日, G53 (1992).

[18] 柴田淳広 他: PUREX 再処理工程への晶析法の導入 に関する検討. 日本原子力学会 1999 年秋の大会, 新渴工科, 9 月 $10 \sim 12$ 日, K49 (1999).
[19] Baron, P. et al.: State of progress of the DIAMEX process. GLOBAL'97, Oct.5-10, 1, 366-370 (1997).

[20] Song, C. et al.: Treatment of high saline HLLW by total partitioning process. GLOBAL'97, Oct.5-10, 1, 475-480 (1997).

[21] Kubota, M. et al.: Development of the four group partitioning process at JAERI. NUCEF'98, JAERI-Conf 99-004, 1, 210-214 (1999).

[22] Koma, Y. et al.: A counter current experiment for the separation of trivalent actinides and lanthanides by the SETFICS process. . Solvent Extr. Ion Exchange 16, 6, 1357-1364 (1998).

[23] Bychkov, A.V. et al.: Pyroelectrochemical reprocessing of irradiated FBR fuel. III. Experiment on high burn-up Fuel of BOR-60 Reactor. GLOBAL'97, Oct.5-10, 2, 912-916 (1997).

[24] Harmon, K.M. et al.: The Salt Cycle Process. In: Progress in Nuclear Energy. Series III,429-460 (1970).

[25] 金属燃料サイクル技術研究専門委員会 編: 金属燃 料サイクル技術一その現状と将来の見通し一. 日本 原子力学会(1995). 